DOI: https://doi.org/10.32839/2304-5809/2019-11-75-191

UDC 378.091

Kondratska Halyna

Istitute of Physical Culture and Health Drohobych State Pedagogical Ivan Franko University

\title{
DEVELOPMENT OF SOCIAL AND CIVIL COMPETENCIES OF HIGH SCHOOL STUDENTS
}

Summary. The article critically justified the normative and legal principles of formation of social and civil competence of high school students, shows its significance for young generations. There are revealed the principles (socialization and civil position), approaches (culturological, individual, integrative, personal) of formation of social and civil competence of students abroad and in Ukraine. The ways of social and civil competence formation are determined (development of personal and professional qualities, social activity, social experience, defining priority of integrated multi-level and multi-componental formation of school environment, that unites the views).

Keywords: social, civic, competence, education, student.

Кондрацька Г.Д.

Інститут фізичної культури і здоров'я Дрогобицького державного педагогічного університету імені Івана Франка

\section{РОЗВИТОК СОЦІАЛЬНО-ГРОМАДЯНСЬКИХ КОМПЕТЕНТНОСТЕЙ У СТУДЕНТІВ ВИЩОї ШКОЛИ}

\begin{abstract}
Анотація. У статті теоретично обгрунтовано нормативно-правові засади фрормування соціально-громадянської компетентності студентів, окреслено їі значення для молодого покоління. Розкрито принципи (соціалізації та громадянської позиції), підходи (культурологічний, індивідуальний, інтегрований, особистісний) до формування соціально-громадських компетентностей студентів закордоном та в Україні. Визначено шляхи формування соціально-громадянської компетентності студенті (розвиток особистісних та професійних якостей, соціальну активність, накопичування соціального досвіду; визначення пріоритетності інтегрованого, багаторівневого та багатокомпонентного утворення шкільного середовища, що об’єднує світоглядні позиції педагога). Обірунтовано компоненти соціально-громадянської компетентності студентів закладів вищої освіти: система освіти формуеться на принципах соціалізації та громадянської позиці; навчальний простір як інтегроване утворення нормативно-правових, культурологічних, економічно-політичних знань; включення сучасного педагога в життедіяльність освіти. Визначено критеріїв формування соціально-громадянської компетентності студентів ЗВО: адаптації до сучасних вимог освіти; стійка сформованість соціально-громадянської позиції; педагогічна практика, тому що саме в діяльності, у взаємодії з учнями можна переконатися у своїх досягненнях та визначити перспективи на майбутнє.
\end{abstract}

Ключові слова: соціальна, громадянська, компетентність, освіта, студент.

Tntroduction. Social and civic competencies Lare connected with the ideas of democracy, justice, equality, human rights, well-being and healthy lifestyles, with awareness of equal rights and opportunities of a person. The international community stands on the rights of democracy and equality of various strata of the population. Building a system of foreign education forms the view policy of youth on the rights of culture, politics and economics. Awareness and self-expression is the priority of the modern civil society.

Understanding the importance of civic education to form an active social position is caused by many problems of modern youth that attracts the attention of the Governments of European countries and the bodies of the Council of Europe and the European Union.

Analyzing the modern approaches of socialization of students, we appealed to the developed European Government of concepts and programmes on civic education [3]. This provide us the opportunity to understand how to direct the educational process of the formation of social and civic competencies of students.

We have taken into account the recommendations of Alekseeva V. [1], Grebenyk T. [4], Hrytyak L. [5], Ivzhenko Yu. [7], Shaygorodsky Yu. [16], on educating democratic citizenship of young peo- ple through the formation of democratic and social values. An important problem of our country is the ability to prepare young people for the fleeting changes that are observed in our society today. The definition of conditions for formation of social and public competencies in the student space is one of the most important tasks of education.

Analyzing the British National training Program increating democracy, attention is drawn to students' preparation for effective participation in public life. Learning on the fundamentals of human rights and freedoms is regarded as a founding element of civic education [3]. Also, the analysis of the modern education system in Germany makes it possible to understand that the formation of a German civil identity in EU conditions is carried out with the help of such modern methods: learning by examples, problematic approaches, using contradictory data from the court practice of different countries, participation in civic education of a wide range of NGOs, practical orientation of civic education, i.e. providing students with opportunities to familiarize themselves with the activities of authorities and public Organizations [3].

We offer the education system of Poland and Lithuania as an example in the formation of public competencies. In Poland, civic education of schoolchildren and young people developed in the nineties 
of the last century, along with deep socio-economic and political changes, the beginning of which laid the solidarity movement. At first it was initiatives of organizations and people who saw in the implemented civic education the opportunity to contribute to the formation of civil society and democratic institutions of power [3]. Reforming the education system in Ukraine requires the formation of social and civic position of the teacher, which should be the driving force in the socio-cultural, economic and political life of each child.

The purpose of the study is to disclose the development of students ' social and civic competencies based on professional education.

Review of recent publications. In Ukraine there is a number of normative and legal acts on the formation of the content of social and civic education of a young man, namely: on September 5, 2017 the Supreme Council of Ukraine adopted the law "on education"; National strategy of Education Development in Ukraine for the period up to 2021; The concept of the new Ukrainian school August 14, 2017; National doctrine of educational development; State standard of basic and full secondary education; Law of Ukraine "on general secondary Education", Law of Ukraine "on higher education", strategy of civic education development for the period up to 2022. Basic policy of education forming teachers as creative, constructive, organizational, diagnostic, important for reproduction of social potential. Its position provides the educational impact of not only mental but also physiological nature. In this regard, his socio-pedagogical functions (educator, organizer, researcher) are constantly expanding and complicated. Professional skills of teachers include: the presence of pedagogical talent; aspiration to work in the field of education and science; typological features of the nervous system that characterize the strength, motility and balance of the main mental processes; good physical condition; high total, intellectual and aesthetic culture; moral and legal consciousness, etc.

The sociological approach to the problem of socialization of a modern teacher focuses on the belonging of a person to a certain social community that is reflected in it, influences on her worldview, ideals, values, attitudes and norms of behaviour, character traits, psychology, etc. [1]. According to Alekseeva V. [1], Bezpalo O. [2], socialization of students is a socio-pedagogical problem. The researchers propose to pay attention to the analysis of formation of the students' mobility, dynamism and internal needs of correlation of personal aspirations with interests of society. Also the system principles of socialization, forms and methods of engagement, which are based on voluntarity, choice of directions, activity and self-activity of students. It is theoretically proved that in the process of activity the personal and professional qualities are formed, social activity is developing, social experience is accumulated.

The second component of social and civic competence of students is a civic position towards revealing directions of educational environment in the system of general secondary education. The first task is to determine the civic culture of the student. Ivzhenko offers to consider the civic cul- ture as a perception of its belonging to the aggregate of achievements of civil society and emotional attitude to the historically acquired complex of material and civic values, rules, traditions, beliefs. For students, it is manifested in the preservation and development of civic culture and harmonising relations in society [7].

Ivanyuk I.V., Ovcharuk O.V., Tereschenko A.B. conducted an analysis of definition of a sense of citizenship as a complex of spiritual and moral experiences of the person for the fate of the motherland, which is manifested in the feeling of patriotism, moral and aesthetic feelings, national and cultural identity, civic dignity, civic responsibility, civil obligation, civil conscience, civil courage, respectful attitude and love to the native land, which is reflected in the socially actions aimed at ensuring the social interests and human rights. As well as the change of the social environment in accordance with the moral values and relevant social tasks. Therefore social and civic competence is a dynamic combination of knowledge, ways of thinking, opinions, values, skills, abilities and other personal qualities that determine a person's ability to successfully conduct professional or further training activities.

Results of the study. Having analyzed the conception of the civic education of the individual APS of Ukraine (2000), where underlined that citizenship is an integrated quality of the person, which is formed in the process of upbringing, we have concluded that the citizenship is multifaceted Concept and fundamental spiritual-moral quality, worldview characteristics of the personality, which has cultural basis and caused by its state self-identification, awareness of belonging to a particular country [11]. This is associated with human rights to the prevailing traditions of the state, the laws, the law, the welfare of civil society, the willingness to perform duties, and to assert their own rights [10]. In the concept of civic education [10] and the law of Ukraine "on education" [6] education in Ukraine has established innovative ways of civic education and is formed on the principles of individualization and priority of educational services.

Social and civic competence of the teacher forms knowledge about rights, interests and needs of the child. Each young person has the right to participate in the formation and implementation of State youth policy; to promote youth involvement in public civic activism.

Having analyzed the scientific researches [9; 13-18], we found out that the socio-civic competence of young people in higher education institutions is formed in a complex manner by means of knowledge, skills, qualities and practical experience of the civil activity on human values orientation. Education is an open system that includes requirements, conditions and resources brought into it from the external scientific environment. In the culturological space professional education of the teacher is presented as an educational process in which the student and the teacher realize themselves as subjects of culture, and the content of education is built according to the content of pedagogical culture, and using of personal-oriented technologies, cultural criteria and assessments of teacher readiness to professional pedagogical 
activity [2]. Other scholars $[11 ; 12]$ note that professional training should be considered due to the outcome or process of its receipt as a collection of special knowledge, skills and abilities, qualities of professional experience and norms of behavior that provide the possibility of successful activity in a certain profession. Therefore, given the contents of the general concept of "preparation", the content of the concept "professional training is proposed in the following aspects:

- from the point of view of its organizers is the process of creation of scientific and pedagogical workers and the heads of conditions for purposeful formation and development in future specialists competence and ability to professional activity;

- from the point of view of students is the process of achieving them necessary level of preparedness, which would provide readiness to perform actions on purpose;

- as a result of professional training it is the readiness of its subjects to professional activity.

In our opinion, one of the criteria for adapting the teacher to the modern requirements of training is the stable formation of social and civic competence through pedagogical practice, because it is in activity that in interaction with pupils can be convinced of their achievements and to identify future prospects. Analyzing the proposals of scientists to certainty the needs of social and civic competence of students, we came to the opinion that the professional culture of the future teacher, as well as their experience gained during study and practice leads to the following conclusions: the development of professional-pedagogical culture of teachers depends on formation of spiritual and moral values of society; it takes place in the process of mastering all training courses of pedagogical education, but the special opportunities have pedagogical disciplines; forming of professional-pedagogical culture of teacher can take place on such algorithm: diagnostics of formation of qualities of student; assimilation of the theoretical base; drawing up plans for self-development of basic traits inherent in a specialist with high professional culture; performing exercises, participation in training programs; realization of personal qualities and checking of professional culture during pedagogical practice. In the institutions of higher education is brought up patriotism, internationalism, democracy, dignity, discipline, responsibility, conscience, honesty, fidelity, fairness, respect and diligence.

The human qualities outlined above form a person of the teacher as a carrier of social and civic position, which can be associated with obtained competencies according to the results of studies in the HSI.

The period of study in higher education institutions can be considered as the stage of personality formation, which emphasizes the highest activity, development of cognitive motivation, establishment of professional self awareness, understanding of meaning of life and recognition. Also, the stage of research work makes it possible to develop independence, self-determination in a new circle of communication, meaningful decision-making, formation of professional direction of personality, increased demand for communication. Third stage of practical work and social experience in the process of interpersonal communication, mastering the subject accumulated knowledge, skills, produced values. At this stage, the objective is made through the interaction and regulation of interests; external and internal relations; coordination of actions according to external environment. Higher education institutions as community centers and traditional spiritual centers of the local community should contribute to the development of a democratic political culture of future teacher, the formation of civic competence, political and legal knowledge and civic responsibility of young people for the future of education.

Vocational education should be an integral system of measures, methods and techniques; taking into account the personal qualities of a specialist; have a clearly defined structure and specificity. It should integrate the complex of different approaches to civic education (formal, informal, informative), as well as to take into account all the components of education, all levels of education and all age groups of citizens, in particular adult education, and to be aimed at formation of civic competencies.

Social and civic competence of the teacher should determine the trajectory of modern education in school environment:

- allowing the senior pupils to choose the type of research work;

- promoting the formation of students' skills of obtaining information from the CD-room;

- promoting education of important qualities by giving them opportunities to perform different roles in the process of leisure.

Orientation of school education to determine the legal norms of a pupil (young person) in a society, his needs and opportunities (patriotism, democracy, responsibility), faith and expectations (conscience, honesty, integrity), culture and achievement (fairness of respect and diligence).

This is an integrated, multilevel and multicomponent formation of school environment that unites worldview positions, as well as diagnostic-prognostic, educational-development, health-preventive, educational-methodological, educational, communicational, healthsaving, control, monitoring, physical and educational aspects of its activities are the important characteristics of creative pedagogical activity, aspiration for socio-pedagogical activity, spiritual and physical self-improvement of teacher's personality. At the same time, the sense of socio-civic responsibility of the teacher for the future of its own people should promote the participation of young generation in transformation of the society. The transition to social-civil society involves ensuring public activity, rapid socialization, social stratification and real inclusion of student in socio-economic, political, spiritual and other processes.

Conclusions. Social and civic competence of students of higher education institutions is formed on the principles of socialization and civic position, in law-legal, culturological, economic-political space as integrated, multilevel and multicomponent formation, which has the provision of public activity, rapid socialization, social stratification and the real inclusion of modern teacher in the process of education. 


\section{References:}

1. Alekseeva, V. (2016). Socialization of students in post-cultural activities as social and pedagogical problem. Pedagogical Sciences: Theory, history, innovative technologies, no 5(59), pp. 419-425.

2. Bezpalko, O. (2003). Social pedagogics in schemes: Textbook. Kyiv: Center of Educational Literature, $134 \mathrm{p}$.

3. Figueroa-Rodríguez, B., Figueroa-Sandoval, B., Figueroa-Rodríguez, K.A. (2012). Competence training in higher education: the case of the technological master "Prestación De Servicios Profesionales" from The Colegio De Postgraduados (México). Procedia - Social and Behavioral Sciences, 46, 2389-2393.

4. Grebenyk, T. (2011). Management of the process of civic education of higher educational institution students. Dis. ... PhD. Pad. Sciences: 13.00.06. Sumy, 283 p.

5. Hrytyak, L., Hrytsyak, L., \& Kalinina L. (2009). Public-Public administration of education development at the State, regional, institutional levels. Strategic priorities, no. 3(12), pp. 59-66.

6. Ivanyuk, I.V., Ovcharuk, O.V., Tereschenko, A.B. Analytical report on the current state of civic education in Ukraine. URL: http://lib.iitta.gov.ua/844/1/civic_education.pdf

7. Ivzhenko, Yu. (2014). Peculiarities of the activity of student NGOs as a factor of formation of social activity of personality. Scientific notes of Nizhyn Mykola Gogol State University. Psychological and Pedagogical Sciences, no. 4, pp. 32-36.

8. Key Competences (2002). A Developing concept in general compulsory education Eurydice, p. 16.

9. Kondratska, H., Chpepelyuk, A., Prots, R. (2018). Educationology as the main component in the formation of professional competencies of future specialists of physical culture and sports. Social Work and Education, vol. 5, no. 3, pp. 65-74.

10. Law of Ukraine "on education". Information of the Verkhovna Rada of Ukraine (BD). 2017. No 38-39. Century. 380.

11. Lozano, J.F., Boni, A., Peris, J., \& Hueso, A. (2012). Competenciesin Higher Education: A Critical Analysis from the Capabilities Approach. Journal of Philosophy of Education, $4 \mathrm{p}$.

12. Mulder, M., Gulikers, J., Biemans, H.J., \& Wesselink R. (2010). The new competence conceptin higher education: error or enrichment? / In: Münk D., Schelten A. (Hrsg.) Kompetenzermittlung für die Berufsbildung, Verfahren, Probleme und Perspektiven im nationalen, europäischen und internationalen Raum. Bonn: Bundesinstitut für Berufsbildung.

13. Nussbaum, M. (1997). Cultivating Humanity. A Classical Defense of Reform in Liberal Education. Cambridge University Pres.

14. Nussbaum, M. (2002). Education for Citizenship in an Era of Global Connection. Studiesin Philisophy and Education, no. 21.

15. Pometun, O.I. (2005). Formation of Civic competence: view from the position of modern pedagogical science. Herald of school exchanges programs, no. 23.

16. Shayhorodskyi, Yu. (2013). Civil society in Ukraine. Factors and peculiarities of formation. Modern Ukrainian politics. Kyiv: Center of Social Communications, no. 28, pp. 323-334.

17. The concept of civic education and upbringing in Ukraine (2012). URL: http://osvita.khpg.org/index. php?id=976003974

18. Velytshko, O.U. (2013). Foreign experience of formation of civic competence of children and youth. Pedagogical Education. Theory and practice, no. 13, pp. 24-29. URL: http://nbuv.gov.ua/UJRN/znppo_2013_13_6 